\title{
Ocular cowpox: transmission from the domestic cat
} to man

\author{
Gerard M O'Connor, Arun Acalam A Thiru, Owen E Caul
}

\begin{abstract}
A clinicopathological case of ocular cowpox is reported. Cowpox is no longer regarded as being enzootic in cattle. The most likely mode of transmission of cowpox to man appears to be from the domestic cat or wild rodents.
\end{abstract}

A previously healthy 18-year-old male student was admitted to hospital in July 1988. He gave a two-day history of left facial swelling and discomfort, followed 24 hours later by what he described as a 'stye' on his left upper lid. His general practitioner started him on flucloxacillin $250 \mathrm{mg}$ four times a day and considered the most likely diagnosis to be mumps. Subsequently, he developed gross left facial swelling and periorbital oedema.

The previous month was spent working in his garden, which is adjacent to a farm in which cows reside. The patient owned a 7 -year-old male cat, which scratched him on the upper left chest three weeks before an influenza-like illness and his initial presentation. The cat had had a previously recorded rash, treated with hormone replacement tablets by the local veterinary surgeon.

Examination revealed visual acuities of $6 / 6$ right and left eye. Both eyes were white and uninflamed and moved normally. There was no evidence of keratoconjunctivitis. The positive clinical findings were a grossly swollen left upper lid and side of face, with associated lymphadenopathy involving the parotid, preauricular, and submandibular glands. There was concomitant ulceration of both left lids medially, with scattered infected nodules mainly in his upper

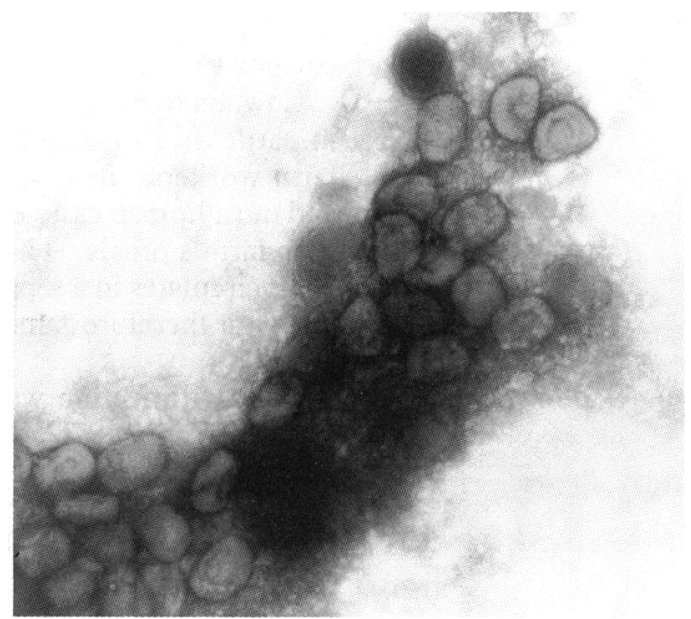

Figure 2: Electron micrograph showing large numbers of cowpox virus. $(\times 20000$. $)$

lid. Systemic examination gave otherwise normal results.

Specific investigations included full blood count, blood culture, and an eye swab for culture and microscopy. Subsequently group I poxvirus was isolated, and further investigations, including electron microscopy, confirmed this to be cowpox. The patient had a neutralising titre of 512 and the cat's titre was 64 . Both are compatible with infection, but in the case of the cat the exact timing of infection cannot be determined. It is most likely that the patient's eye was self inoculated from the lesion on his chest. His condition has now fully resolved and he is pursuing his chosen university career.

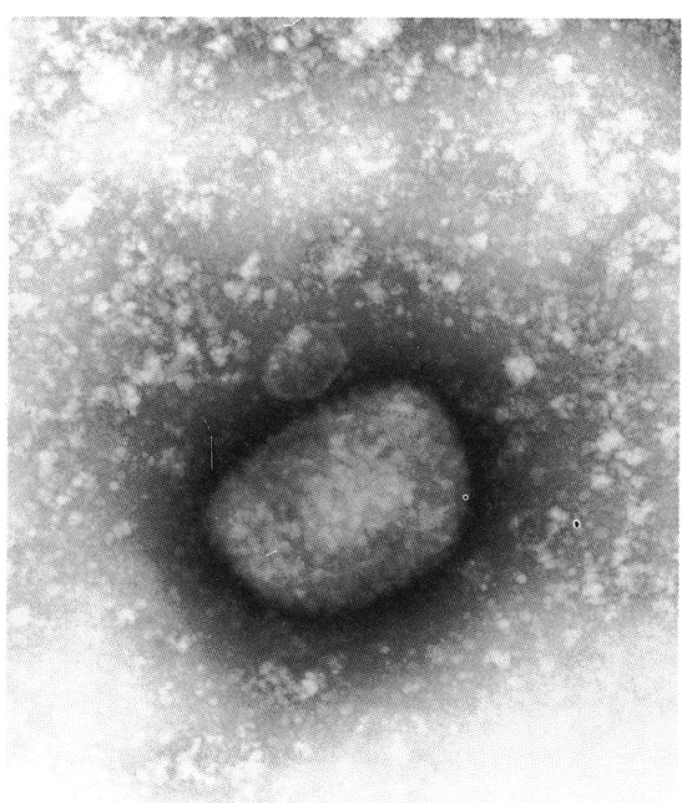




\section{Discussion}

Cowpox has always had a special place in the history of medicine since Edward Jenner first demonstrated in 1798 that immunity to smallpox could be induced by inoculation of material from an animal disease which he called 'cowpox'.' Our understanding of the transmission of cowpox has changed in recent years, specifically as regards its being enzootic in cattle. ${ }^{2}$ Transmission from the domestic cat or some wild rodent now appears to be the most likely mode of transmission of cowpox to man. ${ }^{3}$

Cowpox was previously thought to be enzootic in cattle and to be an occupational hazard for farm workers. ${ }^{2}$ Bovine cowpox is rare in cattle, and most human cases occur without any contact with farm animals. ${ }^{4}$ The suggestion that cowpox virus circulates in a separate domestic or wildlife reservoir therefore gained acceptance in the early 1980s. ${ }^{5}$

Cowpox infection was first recognised in the domestic cat in $1978,{ }^{6}$ though cases were seen in captive cheetahs the previous year. ${ }^{7}$ Twenty to 30 new feline cases are now seen annually by the Bristol and Liverpool University laboratories. ${ }^{8}$ Cats are probably not the original reservoir, as infected cats often show evidence of bites, consistent with a wildlife reservoir. ${ }^{9}$ The reservoir has not been found, but orthopoxvirus antibodies due to cowpox infection are present in some woodmice and voles ${ }^{10}$ and a closely related virus circulates in Russian rodents. ${ }^{1}$

1 Hoeprich PD, ed. In: Infectious diseases. 3rd ed. Philadelphia: Harper and Row, 1983: 872.

2 Baxby Ds cowpox misnamed? A review of ten human cases. BrMed f 1977; i: 1379-81.

3 Fenner F. Poxviruses. In: Fields BN, ed. Virology. New York: Raven Press, 1985: 661-84

4 Anon. Leading article: What's New Pussycat? Cowpox. Lancet 1986; ii: 668 .

5 Dumbell KR. Poxoviruses. In: Wheatherall DJ, ed. Oxford textbook of medicine. Oxford: Oxford University Press, 1983: 2: 5.68-5.73.

6 Thomsett LR, Baxby D, Denham EM. Cowpox in the domestic cat. Vet Rec 1978; 108: 567

7 Baxby D, Ashton DG, Jones D, Denham E. Cowpox virus infection in unusual hosts. Vet Rec 1979; 109: 175 .

8 Hoare CM, Bennett M. In: Grunsell C, Hill F, Raw M, eds. Veterinary annual. 25th ed. Bristol: Wright, 1985: 348-51.

9 Bennett M, Gaskell C, Gaskell R, Baxby D, Gruffydd-Jones TJ. Poxvirus infection in the domestic cat: some clinical and epidemiological observations. Vet Rec 1986; 118: 387-90.

10 Kaplan C, Healing TD, Evans N, Healing L, Prior A. Evidence of infection by viruses in small British field rodents. F Hyg (Lond) 1980; 84: 285-94.

11 Marrenikova S, Ladnyi I, Ogorodnikova Z, Shelukhina E, Maltseva N. Identification and study of a poxvirus isolated from wild rodents in Turkmenia. Arch Virol 1978; 56: 7-14. 